\title{
Building integrated photovoltaics (BIPV)
}

\author{
Panourile fotovoltaice integrate în clădiri
}

\author{
Stud. Alexandra-Maria RUSEN, PhD Stud. Eng. Danut TOKAR
}

Polytechnic University of Timisoara, Romania

DOI: $10.37789 /$ rjce.2020.11.4.3

\begin{abstract}
This paper presents the integrated photovoltaic panels (BIPV) in buildings. They have as their primary purpose the generation of electricity used as an energy resource for buildings or the distribution of energy in the national grid. These systems can provide cost savings on materials and electricity, reduce pollution and add to the architectural aspect of the building. Although these can be added to a structure as functional elements, the biggest challenge for these systems is their inclusion in the initial design of the building.
\end{abstract}

Keywords: photovoltaic panels, materials, integrate systems, architecture

Rezumat: Această lucrare prezintă panourile fotovoltaice integrate (BIPV) in clădiri. Acestea au ca scop primar generarea energiei electrice utilizată ca resursă energetică pentru clădire sau distribuirea energiei în rețeaua națională. Aceste sistemele pot oferi economii în costuri de materiale și energie electrică, pot reduce poluarea și se pot adăuga la aspectul arhitectural al clădirii. Deși, acestea pot fi adăugate la o structură ca elemente funcționale, cea mai mare provocare pentru aceste sistemele este includerea lor în designul inițial al clădirii.

Cuvinte cheie: panouri fotovoltaice, materiale, sisteme integrate, arhitectură

\section{Introduction}

Integrated photovoltaic systems in buildings (BIPV) are designed during architectural design and are added during the construction of the building. These systems do not have supports and mounting elements like the traditional photovoltaic systems. For most integrated solar energy photovoltaic systems, a variety of uses of the energy produced by them as well as their use will be considered to support the specific needs of the occupants of the building [1]. For example, photovoltaic systems generate electricity that can be used for hot water local preparation or to supply with energy for space heating and / or cooling systems.

\section{Integrated sistems- architectural purpose}

These photovoltaic systems can be mounted in different parts of the building, having more or less artistic connection. Thus, they can be applied on the facades of buildings, on roofs or on the architectural 'shell' of the building itself.

On the facades of the buildings the integration of the systems is done on the lateral of the building, replacing the traditional glass windows with semi-transparent solar panels or 
with thin crystals. This variant variant has less access to direct sunlight than the variant with roof integration, but the coverage surface in this case is much more generous [1]. Photovoltaic modules are also available in a wide variety of colors, developed especially for facades. This type of panels are made of a special glass that reflects only the part of the light spectrum that is visible to the human eye, the rest is used to generate electricity. The modules are provided with rails on the back part with which they can be attached to any facade of a standard construction. The rail also offers additional stability. Modules can also be combined with a wide variety of other materials used for facades [2].

In current trends, photovoltaic systems are used in design by architects to camouflage the quality of unattractive or degrading exteriors of buildings (Figure 1).
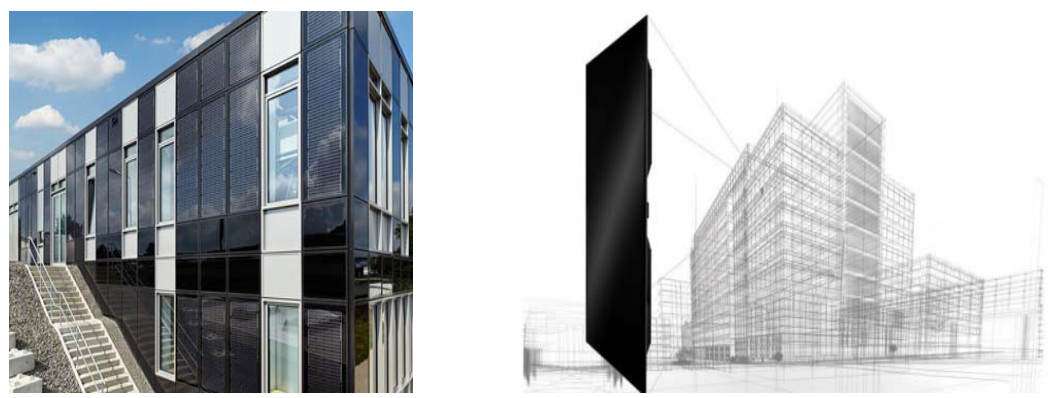

Figure 1. Camouflaged facades

(Sources: Avancis - Powermax Scala Products)

The variant of integration on the roof, offers several applications. First, it can replace the roof itself, and secondly it can replace the material used to finish them. In current trends, solutions are offered by different companies that integrate these systems directly into the roof structure (Fig.2 a), from laminated glass, or systems directly integrated into the roof shingles (Fig.2 b).

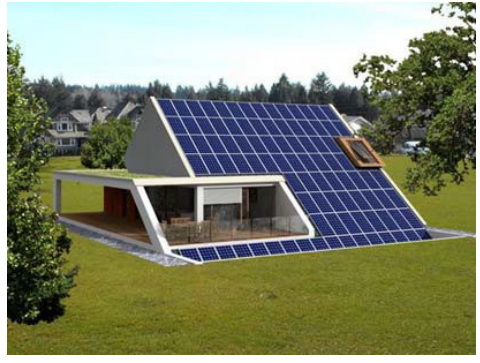

a)

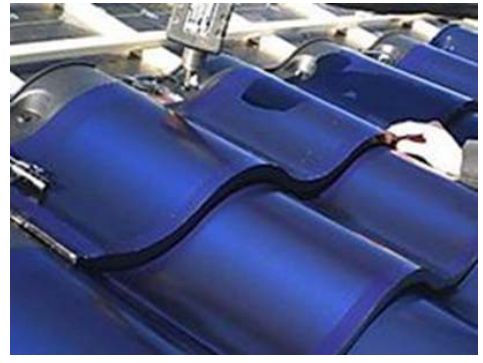

b)

Figure 2.Photovoltaics panel for roof

a) into the roof structure (Sources: http://www.ekokoncept.com),

b) into the roof shingles (Sources: http://www.shtfpreparedness.com

Last but not least, the ultra-thin solar cell solution that is used to create semitransparent surfaces that allow light to penetrate during the day and they also produces electricity, often used in atrias (illuminators) and greenhouses (Fig.3). 
Building integrated photovoltaics (BIPV)
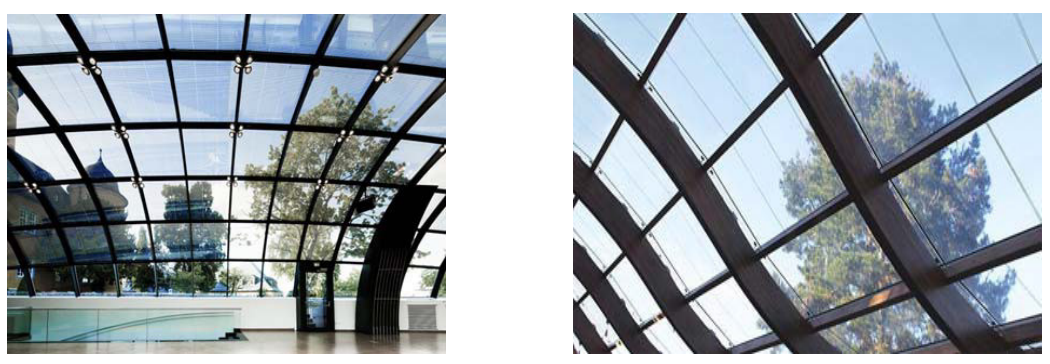

Figure 3. Ultra-thin solar cell solution for atrias and greenhouses [3]

The design of a BIPV system should take into account whether the building works completely independent of the electrical grid, or if it requires batteries or other energy storage systems.

The design of the system is determined by the energy needs of the building and by any structural or aesthetic limitations that may limit the material choices. Silicon crystalline panels have higher electricity output per square meter, but higher costs and design constraints. Thin film materials generate less electricity per square meter, but are less expensive and can be integrated more easily on more surfaces (Fig. 4.) $[4,5]$.
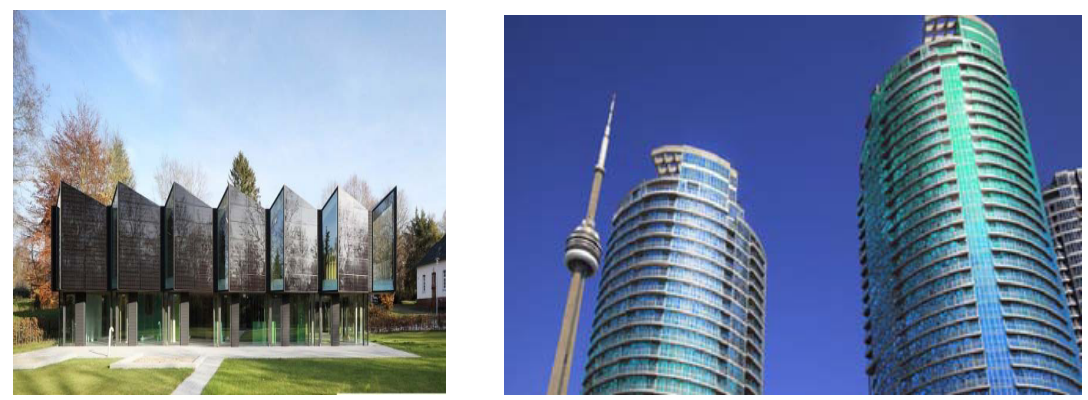

Figure 4. Thin film integrated in the facades of the buildings [4,5]

\section{Case studies- regarding the adoption of BIPV integrated photovoltaic systems and their maintenance}

\section{Integrated photovoltaics in architectural design in China}

The paper shows that we should take into account the function, cost, technology and aesthetics of the folovoltaic panels, rather than just the high integrations. According to developments in technology and market, photovoltaic structures and design should be focused on maintenance and replacement of photovoltaic cell modules, rather than simply extending their life. To solve problems associated with existing photovoltaic structures in China, designing a photovoltaic structure of the building that allows the maintenance and convenient replacement of photovoltaic components [6].

\section{Dubai Frame}

The Dubai Frame is an eye-catching impressive rectangular picture frame-shaped building rising 150 meters (492 Ft) from Dubai's Zabeel Park (Fig.5), spanning 105 meters (344 Ft) horizontally. It attracted a million visitors from around the world during its first year of opening in 2018 and offered them stunning views of the city's past and present. 


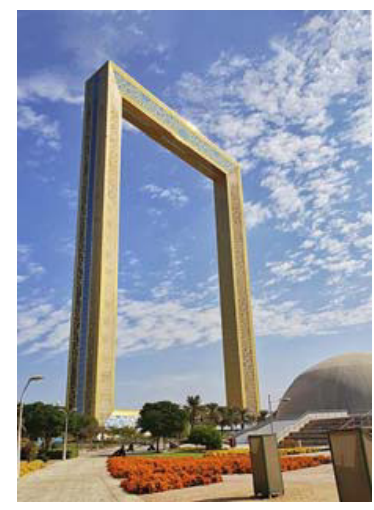

Figure 5. Photovoltaic structure in China [6]

This iconic skyscraper, presented in Fig.6., is considered one of the world's most popular tourist attractions nowadays. Onyx Solar, the world's leading manufacturer of photovoltaic (PV) glass, supplied gold color photovoltaic glass for its rainscreen cladding system.

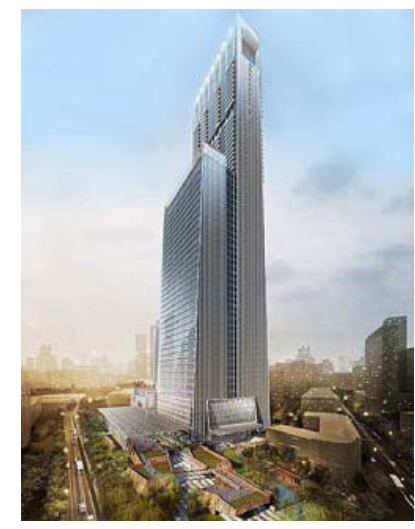

Figure 6. Iconic skyscraper with gold color photovoltaic glass [7]

\section{Tanjong Pagar}

Located in the middle of Singapore's financial center (Fig.7), this 64-story tower is the tallest building in the country. Its design, carried out by S.O.M., the New York-based architectural firm, and construction was commissioned by the Korean multinational Samsung. Onyx contributed with the installation of a large photovoltaic canopy of $27,986 \mathrm{sq} \mathrm{ft}$ covering the main entrance to the building.

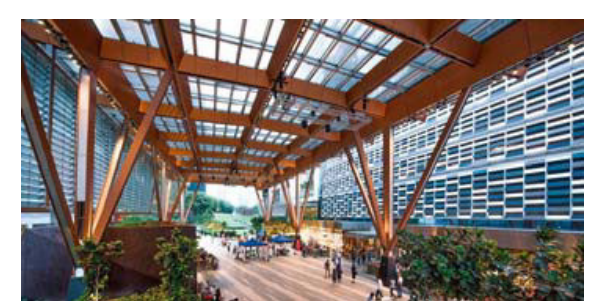

Figure 7. Singapore's financial center [7] 


\section{Coca Cola-Femsa Hq}

The walls of the building are lined with semi-transparent, amorphous silicon photovoltaic glass panes which are anchored to the existing structure, thus enabling air to flow in the space between the panes and the walls of the building (Fig.8). Onyx Solar photovoltaic glass panes were installed on the façade of FEMSA's headquarters, which is the largest Coca-Cola bottling plant company in the world (Monterrey, México). The walls of the building are lined with semitransparent, amorphous silicon photovoltaic glass panes which are anchored to the existing structure, thus enabling air to flow in the space between the panes and the walls of the building. Thanks to this innovative design, these main offices are enjoying natural light, better thermal insulation and cleaner energy with less $\mathrm{CO}_{2}$ emissions. The energy that the glass panes produce covers up to $15 \%$ of the building's energy requirements.

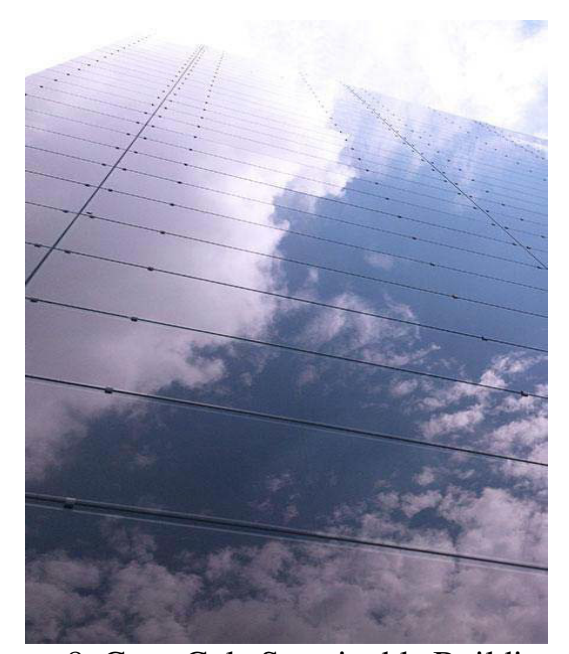

Figure 8. Coca Cola Sustainable Building [7]

\section{Pfizer Genyo Labs}

Thanks to this innovative design, Pfizer offices are enjoying natural light, better thermal insulation and free clean energy with no $\mathrm{CO}_{2}$ emissions (Fig. 9).

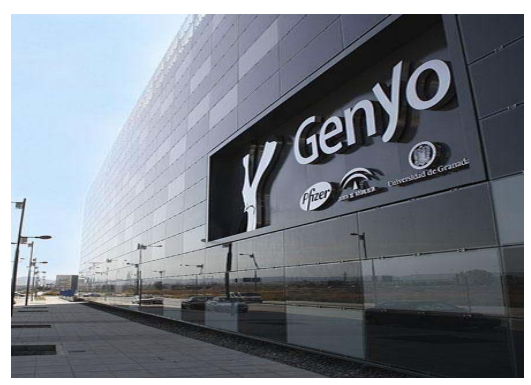

Figure 9. Photovoltaic panels with amorphous silicon glass modules with a semi-transparency degree of 20 [7]

\section{Bell Works}

Bell Works is the product of the successful revitalizationof the two- million-square-foot Bell Laboratories in Holmdel, New Jersey. The mixed-use 'metroburb' is now a popular destination to work, shop, dine and more. Onyx Solar has supplied Bell Works with amorphous silicon photovoltaic glass panes, to cover a total area of $60,000 \mathrm{sq} \mathrm{ft}$, and create the largest photovoltaic skylight in the USA. Because Bell Works is a landmark protected building, Onyx 
Solar had to design glass panes similar to the original ones. These glass modules provide this multipurpose building with a lot of natural lighting by capturing daylight and are also able to produce electricity free of $\mathrm{CO} 2$ emissions (Fig.10).

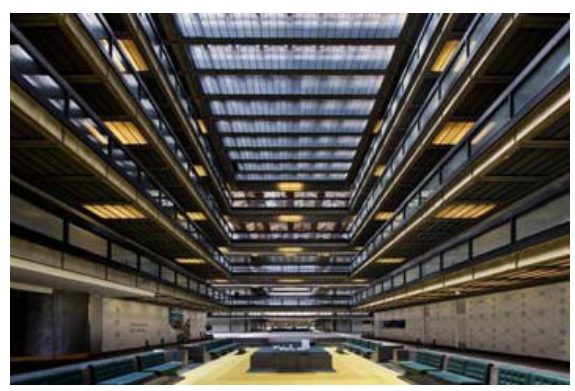

Figure 10. Photovoltaic glass panes similar to the original ones for Bell Works [7]

\section{Conclusions}

The adoption of these integrated photovoltaic systems should facilitate the minimum requirements for the development of renewable energy in buildings and encourage the population to contribute to their development on the market. Installing photovoltaic panels on the facades of buildings can create the illusion of a double facade or by using normal glass and photovoltaic panels in various combinations it can be created the image of a spectacular pixelated glass mosaic of different shades and sizes. Solar architectural applications prove their sustainability through the growth the potential energy generator of a building, but they are one of the most difficult applications because they seal the tire of a building and it is known that transparent surfaces are inherently less efficient than opaque surfaces. However, transparent vertical glass surfaces which represents a high wall-to-roof ratio may require PV integration on these surfaces to achieve a net-zero or nearly net-zero construction goal.

\section{References}

[1] PV Europe, Solar Technology and application, https://www.pveurope.eu.

[2] PV Europe, Solar Technology and application, Facade module available in a variety of colours, https://www.pveurope.eu.

[3] https://mattgieseking.files.wordpress.com/2012/08/r_10121layout.jpg. [4] Solar Power Europe, Building integrated solar. Report from Solar Power Europe's, https://www.solarpowereurope.org

[5] Hall S., Benefits of building integrated photovoltaics, BIPV is an elegant way of producing on-site electricity directly from the sun, 2014, https://www.reminetwork.com.

[6] Changhai Penga, Ying Huanga, Zhishen Wub, Building-integrated photovoltaics (BIPV) in architectural design in China, School of Architecture, Southeast University, Nanjing, PR China.

[7] Onyx solar Grupp, Photovoltaic glass for buildings, https://www.onyxsolar.com. 